\title{
A specimen of Paralycoptera Chang \& Chou 1977 (Teleostei: Osteoglossoidei) from Hong Kong (China) with a potential Late Jurassic age that extends the temporal and geographical range of the genus
}

Tze-Kei Tse, Michael Pittman, Mee-mann Chang

We describe a Mesozoic fish Paralycoptera sp. (Teleostei: Osteoglossoidei), on the basis of a postcranial skeleton collected from the volcaniclastic mudstones of the Lai Chi Chong Formation of Hong Kong, China. The new finding - representing the city's first Mesozoic fish - extends the geographical distribution of Paralycoptera from eastern mainland China into Hong Kong, demonstrating a wider distribution than previously appreciated for this genus. A radiometric age for the Lai Chi Chong Formation of $146.6 \pm 0.2 \mathrm{Ma}$ implies a temporal range expansion for Paralycoptera of approximately 40 million years back from the Early Cretaceous ( 110 Ma). However, spores found in the Formation suggest an Early Cretaceous age that is consistent with the existing age assignment to Paralycoptera. We argue that the proposed temporal range extension is genuine because it is based on recent high precision radiometric age data, but given the discrepancies with the biostratigraphic ages further investigation is needed to confirm this. This study provides an important step towards revealing Hong Kong's Mesozoic vertebrate fauna and understanding its relationship to well-studied mainland Chinese ones. 
2 Tze-Kei Tse ${ }^{1}$, Michael Pittman ${ }^{1, *}$ and Mee-mann Chang ${ }^{2}$

3

41 Vertebrate Palaeontology Laboratory, Life and Planetary Evolution Research Group, Department of

5 Earth Sciences, The University of Hong Kong, Pokfulam, Hong Kong, China.

6

72 Key Laboratory of Vertebrate Evolution and Human Origin of Chinese Academy of Sciences,

8 Institute of Vertebrate Paleontology \& Paleoanthropology, Chinese Academy of Sciences, 142

9 Xizhimenwai Street, Beijing, 100044, China.

10

$11 *$ Corresponding author: mpittman@hku.hk

12 
13 Keywords Jurassic, fish, osteoglossomorph, Paralycoptera, Hong Kong, Lai Chi Chong Formation, 14 lacustrine, volcanism

15

16 17

18

19

20

21

22

23

24

25

26

27

28

29

30

31

32

33

34

35

36

37

38

39

40

41

42

43

44

45

46

47

48

\section{Introduction}

In the summer of 2013, a fish fossil - SHGM L275 - labelled as a plant was discovered in the collections of the Stephen Hui Geological Museum (SHGM) at the University of Hong Kong (HKU). The fossil ( $2 \mathrm{~cm}$ long) is hosted within a small mudstone fragment $(5 \mathrm{~cm}$ by $3 \mathrm{~cm})$ that was supposedly collected from the Lai Chi Chong Formation (荔枝莊組) of Lai Chi Chong, Tolo Channel, north-eastern New Territories, Hong Kong (Fig. 1). This provenance information is based on the specimen label, which appears to be correct, given that all fossils with the same catalogue number are lithologically similar and match the locality's expected lithologies (see Section 4). It is not mentioned in the literature - probably because of its incorrect specimen label - unlike a fossil fish specimen from other Lantau Volcanic Group rocks in Shek Pik (石壁), Lantau Island (Campbell et al. 2007), which has a passing mention in Lee et al. (1997) (Fig. 1). The latter specimen is supposed to be in the SHGM collections, but as it could not be located, it is assumed to have been lost. A fossil fish is also known from the summit area of Lantau Peak (鳳凰山), Lantau Island (C.M. Lee, personal communication, July 19th, 2014) (Fig. 1), but the exact location of this discovery is unknown. Thus, this specimen could belong to the Early Cretaceous Kau Sai Chau or Repulse Bay Volcanic Groups (141.1 $\pm 0.2 \mathrm{Ma}$ and $142.8 \pm 0.2$ Ma respectively) because these rocks outcrop in the upper and lower parts of Lantau Peak respectively (Campbell et al. 2007). The fish fossil assemblages of Lai Chi Chong and Lantau Island are therefore important to compare, but the lack of available specimens from the latter currently prevents this comparison.

The plant fossils discovered from the Lai Chi Chong Formation e.g. Cyathidites, Classopollis and Cicatricosisporites, suggest an Early Cretaceous age for the fossil beds (Lee et al. 1997). However, high precision $\mathrm{U}-\mathrm{Pb}$ single crystal zircon dating of coarse crystal tuff from the upper Lai Chi Chong Formation suggests that the Formation is $146.6 \pm 0.2$ million years old, which corresponds to the Tithonian stage of the Late Jurassic (Campbell et al. 2007), some 40 million years earlier. The high sampling and analytical standards applied to obtaining the radiometric age for the Lai Chi Chong Formation (see Campbell et al. 2007 for details) suggests that its numerical age is unequivocal and that the plant fossil evidence deserves further detailed investigation.

This study focuses on the identification of SHGM L275 and understanding its ecology in the context of the palaeoenvironment of the Lai Chi Chong Formation, that has been inferred from its geology and plant fauna (Lee et al.1997) (Fig. 2). 


\section{$50 \quad 2 \quad$ Methods and Materials}

52 The studied fossil specimen, SHGM L275, is a partially-preserved articulated bony fish skeleton that is 53 missing its anterior portion (Fig. 3). The specimen shows the dorsal, anal and caudal fins and is 54 preserved in a laminated, non-fissile, pale grey orange-spotted mudstone from the Lai Chi Chong 55 Formation (Fig. 3). SHGM L275 is now deposited in the collections of the Stephen Hui Geological 56 Museum (SHGM) at the University of Hong Kong. The specimen was prepared mechanically using a 57 thin needle and was examined under a Leica $S 8 A P O$ stereomicroscope which has a magnification range

58 of 10-80x. Photographs were taken of the specimen using a range of focal points with a Nikon D610 59 DSLR camera mounted to the stereomicroscope. The images were uploaded into the open-access 60 computer software CombineZP (www.combinezp.software.informer.com/) to focus-stack them into 61 fully-focused composite images. Based on a preliminary comparative study against Nelson (2006), 62 SHGM L275 was diagnosed as an osteoglossomorph fish based on the possible presence of an epural 63 and 15 principal branched caudal fin rays (Xu \& Chang 2009). The specimen was then compared by 64 standard methods with other Chinese Mesozoic osteoglossomorph fish from the collections of the 65 Institute Vertebrate Paleontology and Paleoanthropology (IVPP; Beijing, China) and the Stephen Hui 66 Geological Museum (SHGM (HKU), Hong Kong) (see Supplemental Table S1 in the Supplementary 67 Information). The specimen's features were then coded against character lists from osteoglossomorph68 specific phylogenetic analyses (Shen 1996; Zhang 2006; Li \& Wilson 1996; Wilson \& Murray 2008; 69 Xu \& Chang 2009). The review of the osteoglossoid osteoglossomorph Paralycoptera by Xu \& Chang 70 (2009) was particularly important towards the referral of SHGM L275 to this genus because of its 71 details on anatomical variation.

\section{$73 \quad 3 \quad$ Results}

75 The specimen SHGM L275 represents a small fish. The preserved part corresponds to the caudal 76 portion of the fish, with the head and abdominal portion missing. The total length of the preserved part, 77 including the caudal fin, is approximately $18 \mathrm{~mm}$. Twenty vertebrae are identified (Fig. 3) between the 78 anterior part of the dorsal and anal fins and the caudal fin, with the anteriormost being an abdominal 79 vertebra, and the remaining (19) - caudal vertebrae. The number of caudal vertebrae is comparable to 80 many stem osteoglossomorphs, like Huashia gracilis and Jinanichthys longicephalus (Wilson \& 81 Murray 2008). Most of the vertebral centra are dorsoventrally deeper than anteroposteriorly long, 82 which may allow easier lateral movements during propulsion, as in most fishes. In the anterior part of 83 the specimen, there are four circular features directly on the vertebral column (Fig. 3) - these are the 84 anterior rims of the vertebrae. This feature is also present in the osteoglossoid osteoglossomorph 
85 Paralycoptera wui, IVPP V2989.100 (Fig. 4), and in other studied osteoglossomorph specimens like

86 Yanbiania wangqingica, IVPP V6767-1, and Tongxinichthys microdus, IVPP 2332.1 (Wilson \&

87 Murray 2008).

88

In SHGM L275, the anal fin is larger than the dorsal fin like those in Paralycoptera wui (Chang \& Chou 1977; Xu \& Chang 2009). Seventeen fin rays were observed in the anal fin whilst 10 were observed in the dorsal fin, although the actual number of fin rays may be higher because the anterior ends of both fins are incomplete (Fig. 5). However, the fin ray counts - as they are - are the same as those of Paralycoptera wui IVPP V2989.100 and .105, although the fins of the latter specimen are also incomplete, as in SHGM L275. For both the anal and dorsal fins, the lengths of the fin rays are longer in the anterior portion of the fin than in the posterior portion giving them a sub-triangular shape. The preserved anterior margins of the anal and dorsal fins are opposite to each other and are rather close to the caudal fin suggesting that the dorsal fin is posteriorly situated along the fish. Such features, together with the shape of the fins, are seemingly similar to the posterior portion of Lycoptera, but in the latter taxon the size difference between the anal and dorsal fin is not significant compared to SHGM L275. Between the fins and the vertebrae, pterygiophores supporting the fin rays are observed (Fig. 5). The number of pterygiophores is more or less the same as the number of fin rays because the ends of each pterygiophore preserved leads to the base of a fin ray.

In the caudal skeleton of SHGM L275 (Fig. 6), six hypurals were identified. The first one is posteriorly broader, giving a fan-like shape, whereas the second is comparatively narrow. These hypurals articulate with the first ural centrum, and support the rays of the lower lobe of the caudal fin. Under the first hypural, the parhypural, articulating with the preural centrum 1, also has a somewhat fan-shaped broader posterior portion. The second ural centrum is triangular in shape and is slightly upturned towards the upper lobe of the fin. The third to sixth hypurals are rectangular rod-shaped, articulating with the second ural centrum, and supporting the rays of the upper lobe of the caudal fin. Comparing ural centrum 2 with ural centrum 1 and neighbouring vertebral centra, ural centrum 2 is anteroposteriorly longer than dorsoventrally deep whilst the others are dorsoventrally deeper than anteroposteriorly long. In the area above the ural centra 1 and 2, traces of uroneurals can be seen, though it is difficult to estimate their number (possibly two or three). The anterior tip(s) of the uroneurals extend to the posterodorsal end of the preural centrum 1 . An epural is probably present above the uroneurals. No urodermals were found.

Even though the caudal fin rays are poorly-preserved, the caudal fin appears to be symmetrical because the vertebral column only bends slightly towards the upper lobe. Thus, the specimen is likely to possess a homocercal tail, which is a trait of all teleostean fish (Nelson 2006). We were able to find out 
121 the approximate counts of the caudal fin rays: 17 principal fin rays are recognized, seven branched rays

122 with one unbranched ray at the upper margin in the upper lobe, and eight branched rays with one

123 unbranched ray at the lower margin in the lower lobe. Besides, about 5-6 and 3-4 short, procurrent rays

124 are observed in front of the upper and lower lobe respectively. Five neural spines on the 1st-5th preural

125 centra and four haemal spines under 2nd-5th preural centra are prolonged, the posterior ones of which

126 are in support of the procurrent rays. The ural centrum 1, perhaps, also carries a short neural spine (Fig.

127 6).

128

129

130

131

132

133

134

135

136

137

138

139

140

141

142

143

144

145

146

147

148

149

150

151

152

153

154

155

156

Based on the features described above, especially that a possible epural is present, the number of branched caudal fin rays is 15 and the dorsal fin is posteriorly situated, SHGM L275 most likely belongs to the order Osteoglossiformes (Shen 1996, Xu \& Chang 2009), under the superorder Osteoglossomorpha (Greenwood et al. 1966).

SHGM L275 was added to the osteoglossomorph phylogenetic data matrices of Shen (1996), Zhang (2006), Wilson \& Murray (2008), and Xu \& Chang (2009) (Table 1) and in all four analyses the taxon that has the most similar codings was Paralycoptera. However, for the Zhang (2006) matrix, SHGM L275 has more closely matched codings to Singida than to Paralycoptera. The Eocene temporal range of Singida (Xu \& Chang 2009) is at odds with the Late Jurassic age of SHGM L275, but it might be possible that the new specimen supports an extremely large range extension. However, SHGM L275 is referable to Paralycoptera based on additional details of the caudal skeleton: the two hypurals in the lower lobe of Paralycoptera are separated and unfused (Shen 1996) like in SHGM L275, whilst those in Singida are partially fused (Murray \& Wilson 2005). In addition, Singida has a falcate anal fin instead of the triangular one in Paralycoptera (Murray \& Wilson 2005) and SHGM L275.

In comparing SHGM L275 and Paralycoptera based on the above analyses (Tables 1, S2-S5), there were a few character state discrepancies. These unmatched characters include: (1) the condition of the neural spine on ural centrum 1 - whether the neural spine is complete or rudimentary, and (2) the number of epurals. According to Wilson \& Murray (2008), the neural spine on the first ural centrum of Paralycoptera should be absent or rudimentary, whereas Shen (1996) and Xu \& Chang (2009) observe a completely developed neural spine. Zhang (2006) is uncertain about the relative development of this spine, but in SHGM L275 a rudimentary neural spine is present. The number of epurals present in Paralycoptera remains controversial. Shen (1996) identified a single epural in Paralycoptera whereas Xu \& Chang (2009) noted its absence. In specimens IVPP V2989.65, .100 and .105 of Paralycoptera, we also identified no epurals, like Xu \& Chang (2009). An ' $x$ ' has been marked in Table 1 for this character, even though the character state used by Xu \& Chang (2009) - 'one or absent' - should justify the use of a ' $O$ ' mark instead. We therefore advocate the separation of this state in future work in 
157 accordance with Greenwood (1970) and the epural characters of Shen (1996), Zhang (2006) and 158 Wilson \& Murray (2008). There is a possible epural in SHGM L275. Zhang (2006) and Wilson \& 159 Murray (2008) both record uncertainty in the number of epurals in Paralycoptera. The first preural 160 centrum of SHGM L275 has a complete neural spine, as identified in Paralycoptera by all four 161 aforementioned analyses, but Xu \& Chang (2009) mistakenly recorded a 'rudimentary or absent' 162 neural spine in their data matrix. Excluding the aforementioned discrepancies, the four studies 163 otherwise converge on SHGM L275 being a specimen of Paralycoptera. However, Xu \& Chang's 164 (2009) observations of individual anatomical variation within Paralycoptera actually explain the 165 differences in the caudal skeleton observed by Shen (1996), Zhang (2006) and Wilson \& Murray

166 (2008). This therefore confirms that SHGM L275 is a specimen of Paralycoptera (Fig. 7), which in our 167 opinion negates the need for a numerical phylogenetic analysis. Xu \& Chang (2009) synonymised the 168 genus into one species $P$. wui whose features in SHGM L275 are:

169

170

171

172

173

174

175

176

177

178

179

180

181

182

183

184

185

186

187

188

189

190

191

192

(1) a completely developed neural spine on the first preural centrum;

(2) two or three uroneurals;

(3) four upper hypurals and two lower hypurals, and

(4) all hypurals are independent.

\title{
Systematic Palaeontology
}

\author{
SUBDIVISION TELEOSTEI MÜLLER, 1846 \\ SUPERORDER OSTEOGLOSSOMORPHA GREENWOOD ET AL., 1966 \\ ORDER OSTEOGLOSSIFORMES REGAN, 1909 \\ SUBORDER OSTEOGLOSSOIDEI REGAN, 1909 \\ GENUS $†$ PARALYCOPTERA CHANG \& CHOU, 1977 \\ $\dagger$ PARALYCOPTERA sp.
}

\section{Discussion}

\subsection{Ecology of Paralycoptera}

Paralycoptera is a member of both northern China's Lycoptera Fauna and south-eastern China's Mesoclupea Fauna (Chang \& Jin 1996). It has been discovered in Jilin, Liaoning, Shandong, Zhejiang and Fujian provinces (Xu \& Chang 2009) and now in Guangdong Province too (this study) (Fig. 8).

This geographical range is impressive given that the northern part of China has been separated from the south by the Qinling-Dabie Shan orogenic belt since the Late Triassic (Hacker et al. 2004), and the $20^{\circ}$ 
193 difference in latitude between the southernmost and northernmost localities - Hong Kong, Guangdong

194 Province and Tonghua, Jilin Province respectively - a distance of over $2000 \mathrm{~km}$. This geographic

195 distribution may imply that Paralycoptera was adaptable to a wide range of environments compared to

196 other members of the two faunas. However, climate variability over this geographical area was not

197 very significant in the Late Mesozoic - climate change towards more temperate and humid conditions

198 is reflected by geochemical weathering indices (Ohta et al. 2014) with temperatures between $5^{\circ} \mathrm{C}$ and

$19925^{\circ} \mathrm{C}$ reconstructed from oxygen isotope data from sedimentary rocks in north-eastern China (Wang et

200 al. 2013). However, occasional semi-arid periods are indicated by the appearance of the arid plants

201 Ephedripites and Classopollis in Hong Kong (Lee et al.1997), as well as oxygen isotope data from

202 sedimentary rocks in north-eastern China, including from Jilin and Liaoning provinces (Wang et al.

203 2013). Therefore, Paralycoptera most likely lived in areas with a tropical-subtropical climate similar to

204 many modern osteoglossoids, such as Scleropages formosus (Kottelat 2011).

205

206 Paralycoptera localities were all continental basins (Fig. 9) where fluvial or lacustrine deposits

207 dominated (Chang \& Jin 1996) and these have similar lithologies (see Table 2). Vigorous tectonic

208 activity and episodes of volcanism were common in these localities during the late Mesozoic (Chang \&

209 Jin 1996; Chang \& Chou 1977; Li \& Li 2007). The Lai Chi Chong Formation of Hong Kong consists

210 of mainly tuff and tuffaceous sedimentary rocks (Strange et al. 1990). A shallow freshwater lake

211 environment subject to the influence of volcanic activity is indicated by fluvial-lacustrine and

212 volcaniclastic sedimentary facies (Strange et al. 1990; Workman 1991; Sewell et al. 2000),

213 predominantly turbidites (Lai et al. 1996), and the discovery of terrestrial freshwater plant fossils

214 including Equisetites, Cladophlebis exiliformis, Gleichenites gladiatus and Carpolithus (Lee et

215 al.1997). According to Lin \& Lee (2012), the 'parallel laminated fine sandstone and mudstone' facies

216 is the most likely origin of SHGM L275 as the only light-coloured mudstone unit is confined to this

217 facies (grey volcaniclastic mudstone from the western portion of the Lai Chi Chong locaility; Fig. 2).

218 This facies contains fine-grained, cross-laminated, white and grey coloured mudstone representing a

219 depositional environment below the wave base, where suspension currents might affect deposition (Lin

220 \& Lee 2012). The similarities in the palaeoenvironment between Lai Chi Chong and existing

221 Paralycoptera localities (Workman 1991; Chang et al. 2008; Hu et al. 2012; P.J. Chen 1983) provides

222 additional support for the inference that Paralycoptera from Lai Chi Chong lived in shallow freshwater

223 lakes near areas of active volcanism. One potential hypothesis to explain the association of

224 Paralycoptera discovery sites with volcanism is that Paralycoptera may have thrived on the higher

225 nutrient levels in the lake caused by the influx of volcaniclastic material, and/or the warmer water

226 temperatures provided by thermo-tectonic activities. The sedimentary rocks preserved at Lai Chi

227 Chong frequently show syn-sedimentary structures including microfaults, slumps, convolute bedding,

228 load and flame structures, suggesting the occurrence of mass flows that might have been triggered by 
229 episodic volcanic and seismic activity directly related to the local subduction tectonic setting (Sewell et 230 al. 2000; Campbell \& Shaw 2002). This implies that the habitat of Paralycoptera was subjected to 231 episodic catastrophic events and was not a prolonged quiet, tranquil water body. This habitat is 232 possibly similar to the turbid and swift-water habitat of Hiodontiformes - a closely related group to 233 Osteoglossiformes (Gray 1988). These episodic conditions could indicate that Paralycoptera had a 234 high tolerance to environmental stress (highly variable sediment and nutrient input and possible 235 changes in water temperature). However, the association of the fish with volcanism may more simply 236 reflect the higher fossil preservation potential by volcaniclastic sediments, especially given that only 237 one specimen is known among the strata so far. Crucially, the laminated mudstone that SHGM L275 is 238 preserved in represents a relatively stable rather than unstable depositional setting. This also fits the 239 living environments of most modern osteoglossoid fish which tend to prefer still water bodies e.g. 240 Pantodon buchholzi and Scleropages formosus (Moelants 2010; Kottelat 2011). It therefore seems 241 more plausible that Paralycoptera lived in relatively stable water body like their modern counterparts 242 and probably migrated in times of environmental stress (no evidence of mass fish mortality in the rocks 243 showing synsedimentary structures).

\subsection{Geographical distribution of Paralycoptera and the biogeography of the Mesoclupea Fauna}

The discovery of Paralycoptera in Hong Kong extends the geographical distribution (Fig. 8) of the genus $\sim 700 \mathrm{~km}$ further south of the previously most southerly locality in the Baiyashan Formation of Fujian Province (Xu \& Chang 2009). This implies that Paralycoptera was much more widespread than previously thought and suggests that the genus may also be present in other similarly-aged lacustrine deposits in southeastern China (Fig. 9). Paralycoptera is a typical member of the Mesoclupea Fauna (Chang \& Jin 1996) so it is possible that the other members of this fauna such as Mesoclupea, Sinamia and Paraclupea could be found in Hong Kong in the future.

\subsection{Age of the Lai Chi Chong Formation and osteoglossomorph evolution and biogeography}

Another implication of SHGM L275 arises from the age of the Lai Chi Chong Formation. A Jurassic age was originally proposed by Workman (1991) based on the identification of the fossil plants Cladophlebis and Equisetites. However, subsequent studies of spore fossils (including Cicatricosisporites, Klukisporites, Cyaathidites, Classopollis and Pinuspollenite) from exposures of the Formation at Cheung Sheung (嶂上) - 2.5 km south of Lai Chi Chong (Fig. 1) - suggest that the

262 Formation was deposited between the Valanginian to Barremian stages of the Early Cretaceous (Lee et al. 1997) (Table S6). This age determination is closer to the Aptian age of other Paralycoptera 
265 (Table 2). However, as mentioned in the introduction (see section 1), an Early Cretaceous age is not 266 corroborated by the Late Jurassic radiometric age of the Formation (Campbell et al. 2007: $146.6 \pm 0.2$

$267 \mathrm{Ma})$. The Lai Chi Chong Formation is stratigraphically overlain by the Long Harbour Formation

268 (Sewell et al. 2012) which has also been precisely dated at $142.8 \pm 0.2 \mathrm{Ma}$, within the Berriasian stage

269 of the Early Cretaceous (Davis et al. 1997). This gives additional support to the accuracy and reliability

270 of the radiometric ages, which imply that SHGM L275 dates to the Tithonian stage of the Late Jurassic.

271 However, as this age differs from the biostratigraphic ones, the latter warrants further investigation.

272 Thus, a Late Jurassic age is cautiously assigned to SHGM L275 pending further biostratigraphic

273 studies and the discovery of an in situ specimen - the formation and locality information of SHGM

274 L275 are based on its specimen label, but this could not be verified with the fossil's discoverer because

275 they are not known. This conclusion has a profound impact on the origins of osteoglossomorphs, as it

276 means that Paralycoptera was contemporaneous with other Late Jurassic taxa, including Lycoptera,

277 Tongxinichthys and Anaethalion from the Lycoptera Fauna and Sinamia and Ikechaoamia from the

278 Mesoclupea Fauna (Chang \& Jin 1996). Future ecological investigations of these faunas would

279 therefore be valuable towards our understanding of osteoglossomorph origins, especially given the

280 relatively disparate phylogenetic relationships of some of the aforementioned taxa e.g. Paralycoptera

281 and Lycoptera (Xu \& Chang 2009).

Given the freshwater habitats of osteoglossomorphs, migration across an oceanic barrier was unlikely, so these fish should have a Pangean origin (Xu \& Chang 2009). However, the location of their origins, whether in Africa or Asia, has been debated (Wilson \& Murray 2008; Xu \& Chang 2009). The Late Jurassic occurrence of Paralycoptera in Hong Kong provides additional evidence to support the hypothesis (Xu \& Chang 2009) that osteoglossomorphs originated from eastern Asia, as the oldest represenatives of this clade are all known from the Late Jurassic of China, e.g. Lycoptera and Tongxinichthys (Chang \& Jin 1996) instead of Africa, which instead has members with more derived anatomical traits (Xu \& Chang 2009).

\subsection{New phylogenetic characters}

In our study a numerical phylogenetic analysis was not performed because existing data made it possible to assign SHGM L275 to Paralycoptera. However, in the course of this study it was noted that Singida was not easily distinguishable from Paralycoptera on the basis of existing characters relating to the posterior skeleton. Anatomical characteristics such as the degree of fusion in the hypurals and the shape of the anal fin that were not included in exisiting phylogenetic character lists would therefore be useful to include in future phylogenies: 
301 - Hypurals in the lower lobe: [0] = independent; [1] = partially fused; [2] = fully fused.

302 - Anal fin shape: $[0]=$ triangular; $[1]=$ falcate.

303

304

305

306

307

308

309

310

311

312

313

314

315

316

317

318

319

320

321

322

323

324

325

326

327

328

329

330

331

332

\section{Conclusions}

334

335

336 studies in Hong Kong.

\subsection{Limitations and future work}

The taxonomic identification of SHGM L275 was difficult because the fossil is incomplete, and is the only specimen of its kind from Hong Kong. Thus, further discoveries of Paralycoptera in the city (in the Tolo Channel area and on Lantau Island) would help to facilitate further anatomical comparisons with mainland Chinese specimens, providing additional insights into anatomical variation in this taxon (After Xu \& Chang (2009)). To resolve the current discrepancies between the biostratigraphic and radiometric ages of the Lai Chi Chong Formation, and confirm the proposed temporal range extension for Paralycoptera, a reappraisal of current biostratigraphic evidence is required. Radiometric dating of fossil-bearing strata within the Formation will be particularly valuable, if suitable rocks can be identified in the future. A detrital zircon age of the matrix of SHGM L275, as well as of the 'parallel laminated fine sandstone and mudstone' facies it was assigned to (Lin \& Lee (2012) facies scheme), would also lend supporting evidence to the age assignment. However, these three aspects are beyond the scope of this paper to address further. More detailed petrological analysis of the matrix of SHGM L275 using scanning electron microscopy would be valuable for corroborating its facies assignment and facilitating comparisons with the sedimentary facies of other Paralycoptera localities in mainland China, such as in Liaoning province (P.J. Chen 1983). These facies investigations, in addition to comparisons between the floras at these different localities, will be important towards elucidating the palaeoenvironment of Paralycoptera (and its co-inhabitants) in greater detail, particularly in relation to neighbouring volcanic activity. Future fossil collection and petrological analysis of non-Lai Chi Chong Formation Lantau Volcanic Group sediments - such as those on Lantau Island - as well as sediments from the Kau Sai Chau and Repulse Bay Volcanic Groups, will improve our understanding of local variations in the palaeoenvironment of Paralycoptera, and will potentially provide evidence of how this taxon (and its co-inhabitants) responded to the well-documented episodes of Middle Jurassic to Early Cretaceous volcanism in Hong Kong (Sewell et al. 2000). The latter narrative therefore makes Hong Kong an ideal place to understand the biotic response of Mesozoic fossils to significant environmental stress, so it is hoped that this will lead to further development of palaeontological

A fossil fish, SHGM L275, from Lai Chi Chong, Hong Kong was rediscovered in the fossil collections of Stephen Hui Geological Museum at the University of Hong Kong. This specimen is identified as 
337

338

339

340

341

342

343

344

345

346

347

348

349

350

351

352

353

354

355

356

357

358

359

360

361

362

363

364

365

366

367

368

369

370

371

372

Paralycoptera sp. based on the following four anatomical characteristics:

(1) a completely developed neural spine on the first preural centrum;

(2) two or three uroneurals;

(3) four upper hypurals and two lower hypurals, and

(4) all hypurals are independent.

The discovery of Paralycoptera in Late Jurassic-aged strata in Hong Kong - the city's only Mesozoic vertebrate - appears to extend the temporal range of the genus back by $\sim 40$ million years. However, discrepancies between the biostratigraphic and radiometric ages of the strata, which belongs to the Lai Chi Chong Formation, warrants a cautious treatment of the proposed temporal range extension, pending further geochronological investigation. However, our discovery unequivocally extends Paralycoptera's geographical range approximately $700 \mathrm{~km}$ southwards, potentially affecting the Mesoclupea Fish Fauna. In the context of the geological literature on the Lai Chi Chong Formation and our knowledge of the fossil's matrix, it is suspected that Paralycoptera lived in freshwater lakes in close proximity to volcanic environments that experienced episodic earthquakes and volcanic eruptions that greatly affected the lake's regime. This palaeoenvironment appears to match those of other Paralycoptera localities in mainland China inspiring the conclusion that this taxon was potentially tolerant of high environmental stresses and may even have thrived on higher nutrient levels and changeable water temperatures in the lake, during times of volcanic activity.

This study makes an important contribution to our understanding of Hong Kong's fossil heritage, given that the city has a relatively poor fossil record and limited sedimentary rock exposures (Lee et al. 1997). This study is the first on Hong Kong fossils in over 15 years (Lee et al. 1997) so it is hoped that it can help to promote further interest in Hong Kong's palaeontology, particularly given the rare opportunity to study the biotic response to long-lived and accurately-dated Mesozoic volcanic events.

\section{Acknowledgements:}

This study developed from TKT's undergraduate research work at the Department of Earth Sciences of the University of Hong Kong. This comprised of a Summer Research Fellowship funded by the University's Faculty of Science and his final year undergraduate project (EASC3308 Earth Sciences Project) - both of which were supervised by MP. The authors thank the Stephen Hui Geological Museum, the Department of Earth Sciences of the University of Hong Kong and the Institute of Vertebrate Paleontology and Paleoanthropology (IVPP) for loaning their specimens for this study. The Department of Earth Sciences and the Faculty of Science funded the camera and microscopy 
373 equipment used in this study. Mr. Wang Zhao (王釗) at the IVPP is thanked for further preparation of 374 the specimen, and Dr. Wu Feixiang (吳飛羊羽) also from the IVPP is thanked for producing illustrations. 375 We would like to thank Dr. Roderick J. Sewell (Hong Kong Geological Survey), Prof. Desui Miao (苗 376 德歲) (University of Kansas) and an anonymous reviewer for their helpful feedback that improved the 377 quality of this manuscript.

\section{Author contributions:}

TKT and MP collected and analysed the data and also wrote the paper, MMC had some input in the description of the specimen. MP designed the project.

\section{References}

Chang M.M., Chen P.J., Wang Y.Q., Wang Y., Miao D.S. 2008. The Jehol fossils. Amsterdam: Academic Press Chang M.M. \& Miao D. 2004. An overview of Mesozoic fishes in Asia. Mesozoic fishes. 3: 535-563

Chang M.M. \& Jin F. 1996. Mesozoic fish faunas of China. In: Arratia G, Viohl G, eds. Mesozoic fishes - systematics and paleoecology. München: Verlag Dr Friedrich Pfeil, 461-478

Chang M.M \& Chou C.C. 1977. On late Mesozoic fossil fishes from Zhejiang Province, China. Memoirs of the Institute of Vertebrate Palaeontology and Palaeoanthropology, Academia Sinica. 12: 1-59 (in Chinese with English summary) Chen P.J.1983. A survey of the non-marine Cretaceous in China. Cretaceous Research. 4(2): 123-143

Davis D.W., Sewell R.J. \& Campbell, S.D.G. 1997. U-Pb dating of Mesozoic igneous rocks from Hong Kong. Journal of the Geological Society. 154: 1067-1076

400 401

402 403 404 405 406 407 408
Gray J. 1988. Evolution of the freshwater ecosystem: the fossil record. Palaeogeography, Palaeoclimatology, Palaeoecology. 62: 1-214

Greenwood P.H., Rosen D.E., Weitzman S.H., Myers G.S. 1966. Phyletic studies of teleostean fishes, with a provisional classification of living forms. Bulletin of the American Museum of Natural History. 131: 341- 455

Greenwood P.H. 1970. On the genus Lycoptera and its relationships with the family Hiodontidae (Pisces, Osteoglossomorpha). Bulletin of the British Museum of Natural History, Zoology. 19: 259 -285

Hacker B.R., Ratschbarcher L., Liou J.G. 2004. Subduction, collision and exhumation in the ultrahigh-pressure Qinling Dabie orogen. Geological Society of London Special Publication. 226: 157-175

Han X.P., Hao G.L., Liu C., Li Y.B., Lin C.C. 2013. Petroleum geological features and petroleum resources

potential 
in Tonghua Basin. Global Geology. 32(2): 337-343 (in Chinese with English abstract)

Hu G., Hu W.X., Cao J., Yao S.P., Li Y.X., Liu Y.X., Wang X.Y. 2012. Zircon U-Pb dating of the Shipu limestone in Zhejiang Province, coastal southeast China: Implications for the Early Cretaceous environment. Cretaceous Research. 37: $65-75$

Kottelat M. 2011. Scleropages formosus. In: IUCN 2013. IUCN Red List of Threatened Species. Version 2013.2. $<$ www.iucnredlist.org $>$

Lai K.W., Campbell S.D.G., Shaw R. 1996. Geology of the northeastern New Territories. Hong Kong Geological Survey Memoir No.5, Geotechnical Engineering Office, Civil Engineering Department, Hong Kong.

Lee C.M., Chan K.W., Ho K.H. 1997. Palaeontology and stratigraphy of Hong Kong, Volume 1. Beijing: Science Press (In Chinese)

Li G.Q, \& Wilson M.V.H. 1996. Phylogeny of Osteoglossomorpha. In: Stiassny M.L.J., Parenti, L.R., Johnson, G.D., eds. Interrelationships of fishes. San Diego: Academic Press, 163-174.

Li S.J. 1998. Application of the integrative stratigraphy in the study of Mesozoic strata in Shandong Province. Shandong Geology. 14(4): p. 31-36. (in Chinese with English abstract)

Li Z.X. \& Li X.H. 2007. Formation of the 1300-km-wide intracontinental orogen and postorogenic magmatic province in Mesozoic South China: a flat-slab subduction model. Geology. 35: 179-182

Lin H.Y. \& Lee C.Y. 2012. The lithofacies at west of Lai Chi Chong pier. Geological Society of Hong Kong Newsletter. 18(2): 1-4 Moelants T. 2010. Pantodon buchholzi. In: IUCN 2013. IUCN Red List of Threatened Species. Version 2013.2. $<\underline{\text { www.iucnredlist.org }>}$

Müller J. 1846. On the structure and characters of the Ganoidei, and on the natural classification of fish. Scientific Memoirs. 4: 499-558

Murray A.M. \& Wilson M.V.H. 2005. Description of a new Eocene osteoglossid fish and additional information on $\dagger$ Singida jacksonoides Greenwood and Patterson, 1967 (Osteoglossomorpha), with an assessment of their phylogenetic relationships. Zoological Journal of the Linnean Society. 144: 213-228

Nelson J.S. 2006. Fishes of the World. 4th edn. New York: John Wiley \& Sons.

Ohta T., Li G., Hirano H., Sakai T., Kozai, T., Yoshikawa T., Kaneko A. 2014. Early Cretaceous Terrestrial Weathering in Northern China: Relationship between Paleoclimate Change and the Phased Evolution of the Jehol Biota. The Journal of Geology. 119(1): 81-96

Patterson C. \& Rosen D.E. 1977. Review of the ichthyodectiform and other Mesozoic fishes and the theory and practice of classifying fossils. Bulletin of the American Museum of Natural History. 158: 81-172

Regan C. T. 1909. The classification of teleostean fishes. Annals and Magazine of Natural History Series. 8: 75- 86 Schultze H.P. \& Arratia G. 1988. Reevaluation of the caudal skeleton of some actinopterygian fishes. 11. Hiodon, Elops and Albula. Journal of Morphology. 195: 257-303

Sewell R.J., Campbell S.D.G., Fletcher C.J.N., Lai K.W., Kirk P.A. 2000. The Pre-Quaternary Geology of Hong Kong. Geotechnical Engineering Office, The Government of the HKSAR 
445 Sewell R.J., Tang, D.L.K. \& Campbell, S.D.G. 2012. Volcanic-plutonic connections in a tilted nested caldera complex in Hong Kong. Geochemistry, Geophysics, Geosystems. 13(1): Q01006

447 Shen M. 1996. Fossil 'osteoglossomorphs' from East Asia and their implications for teleostean phylogeny. In:

Arratia G,

448 Viohl G, eds. Mesozoic fishes - systematics and paleoecology. Munich: Verlag Dr. Friedrich Pfeil, 261-272

449 Strange P.J., Shaw R., Addison R. 1990. Geology of Sai Kung and Clear Water Bay. Hong Kong Geological Survey

450 Memoir No.4, Geotechnical Control Office, Civil Engineering Services Department, Hong Kong.

451 Taverne L. 1977. Ostéologie, phylogénèse et systématique des téléostéens fossiles et actuels du super-ordre des 452 ostéoglossomorphes, première partie. Ostéologie des genres Hiodon, Eohiodon, Lycoptera, Osteoglossum, 453 Scleropages, Heterotis et Arapaima. Académie Royale de Belgique, Mémoires de la Classe des Sciences. 42: 1-235

454 Wang C.S., Feng Z.Q., Zhang L.M., Huang Y.J., Cao K., Wang P.J., Zhao B. 2013. Cretaceous paleogeography and

455 paleoclimate and the setting of SKI borehole sites in Songliao Basin, northeast China. Palaeogeography,

456 Palaeoclimatology, Palaeoecology. 385: 17-30

457 Wang X.Q. 1985. The geological time of Mesozoic strata in the Mengyin Basin, Shandong Province. Geojournals. 31(6):

458 495-501 (in Chinese with English abstract)

459 Wilson M.V.H. \& Murray A.M. 2008 Osteoglossomorpha: phylogeny, biogeography, and fossil record and the

460 significance of key African and Chinese fossil taxa. Geological Society, London, Special Publications.

295(1):

$461 \quad 185-219$

462 Workman D.R. 1991. Field guide to the geology of the shoreline west of Lai Chi Chong Pier, Tolo Channel.

463 Geological Society of Hong Kong Newsletter. 9 (1): 20-33

464 Xu G.H. \& Chang M.M. 2009, Redescription of $\dagger$ Paralycoptera wui Chang \& Chou, 1977 (Teleostei: Osteoglossoidei)

465 from the Early Cretaceous of eastern China. Zoological Journal of the Linnean Society. 157(1): 83-106

466 Zhang J.Y. 1998. Morphology and phylogenetic relationships of Kuntalunia (Teleostei:

467 Osteoglossomorpha). Journal of Vertebrate Paleontology. 18 (2): 280-300

468 Zhang J.Y. 2004. New fossil osteoglossomorph from Ningxia, China. Journal of Vertebrate Paleontology. 24(3):

$469515-524$

470 Zhang J.Y. 2006. Phylogeny of osteoglossomorpha. Vertebrata PalAsiatica. 44(1): 43-59

471 Zhang S.X. 2009. Geological formation names of China (1866-2000). Beijing: Higher Education Press 
1

The location of the Lai Chi Chong Formation in Tolo Channel, Hong Kong

Figure 1: A map of Hong Kong showing the location of the Lai Chi Chong Formation in Tolo Channel, as well as the broader Lantau Volcanic Group. The approximate locations of fossil fish discoveries in Hong Kong are marked in red. Note that Lantau Peak is now considered to belong to the Kau Sai Chau and Repulse Bay Volcanic groups (Campbell et al. 2007). Scale bar $=10 \mathrm{~km}$ (modified from Sewell et al. 2000).

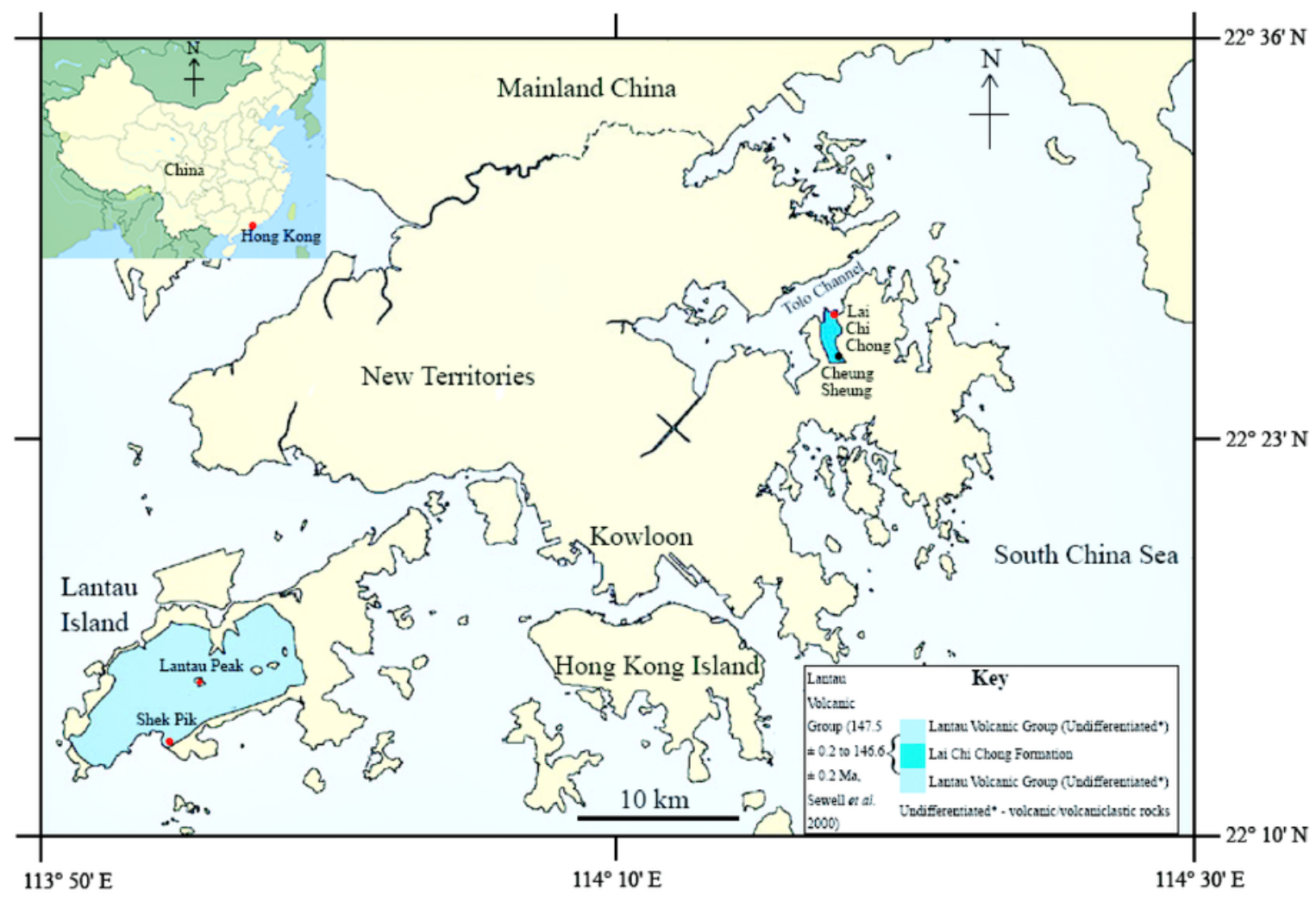




\section{2}

\section{A simplified geological field sketch of Lai Chi Chong, Tolo Channel, Hong Kong}

Figure 2: A simplified geological field sketch of the type locality of the Lai Chi Chong Formation at Lai Chi Chong, Tolo Channel, NE New Territories, Hong Kong (simplified from Workman 1991).

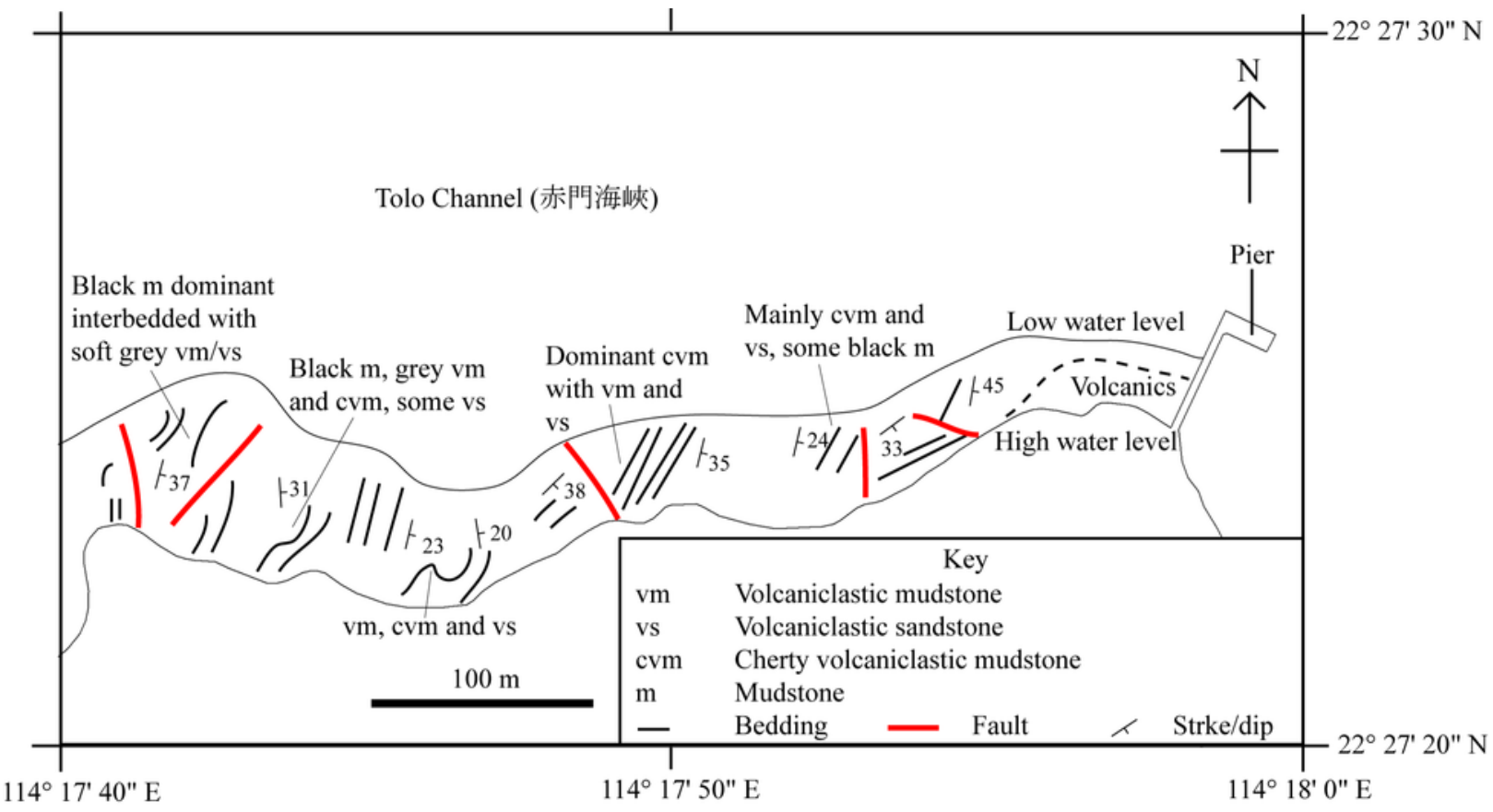


3

Specimen SHGM L275

Figure 3: Magnified image (10.5x) of the specimen SHGM L275. The upper right image was taken before further preparation. The circular features in the anterior portion of the specimen appear to be the anterior rims of vertebrae. Identified vertebrae are numbered from 1 to 20 , with 1 being an abdominal vertebra, and the remaining (19) - caudal vertebrae. Scale bar = $1 \mathrm{~cm}$. 
PeerJ Reviewing Manuscript

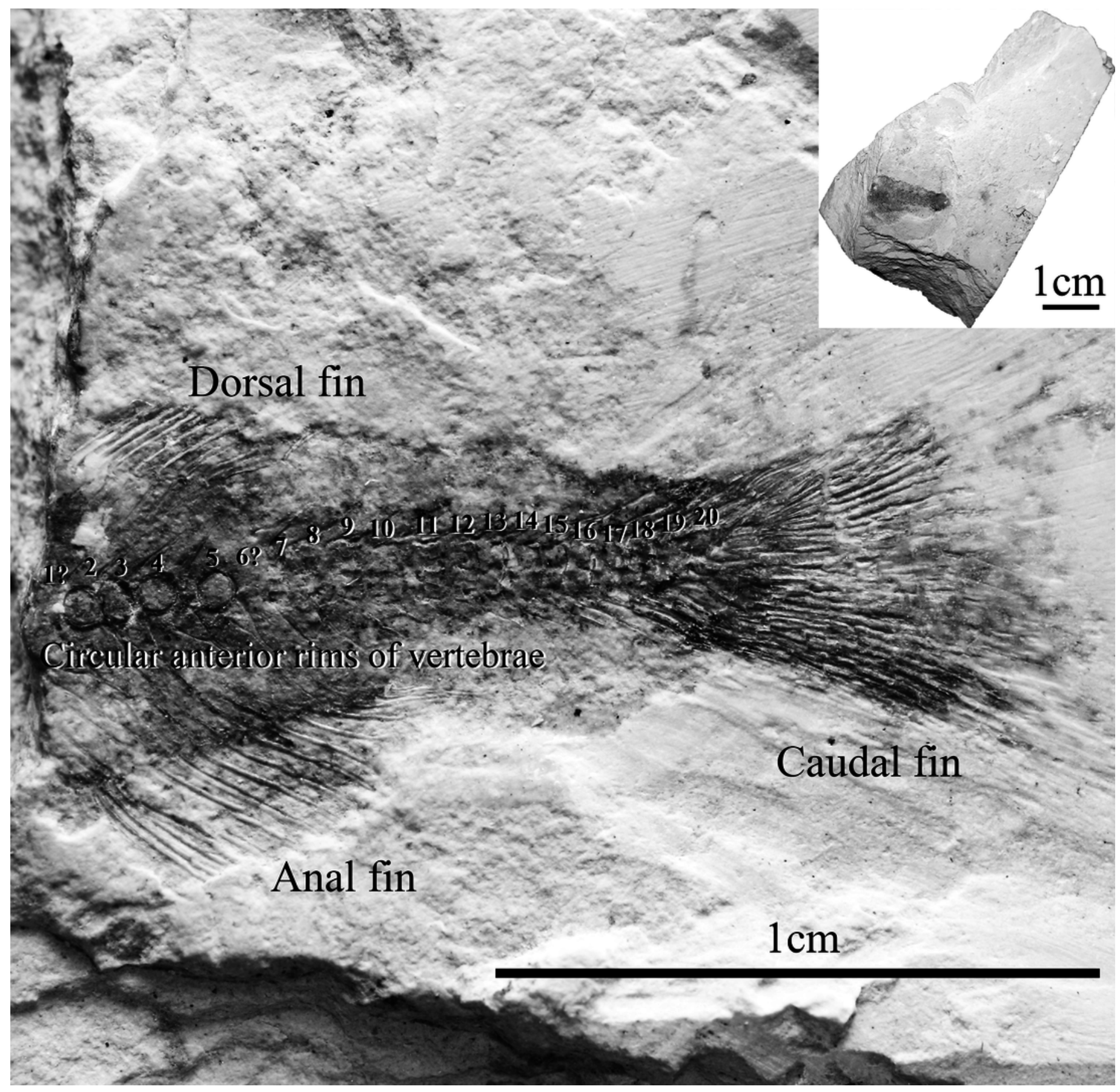


4

Paralycoptera, IVPP V2989.100, reveals numerous circular vertebral rims

Figure 4: Paralycoptera, IVPP V2989.100, has a partially disarticulated vertebral column that reveals numerous circular vertebral rims (most of them are impressions), as in SHGM L275. Scale bar $=1 \mathrm{~cm}$.

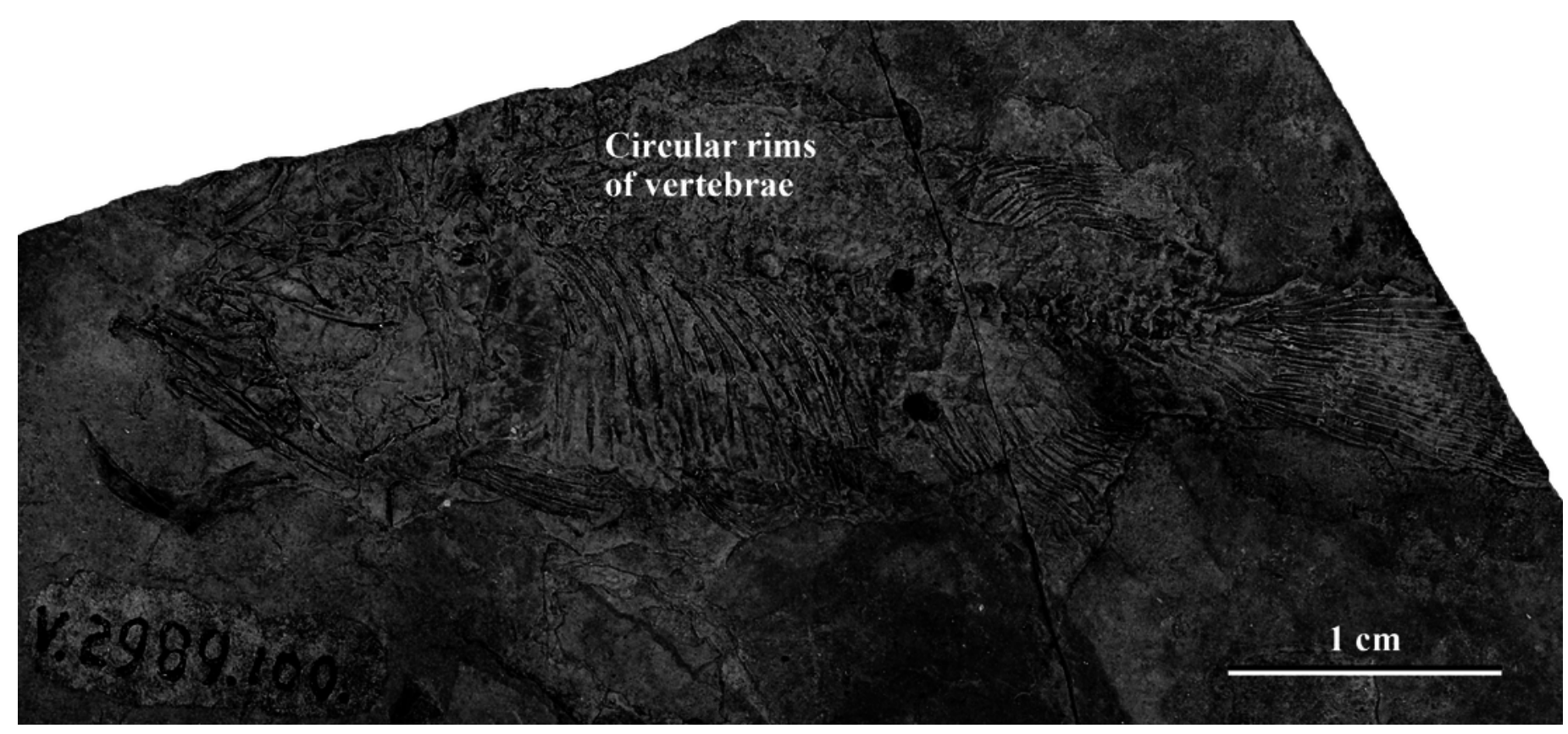




\section{5}

The anterior portion of SHGM L275

Figure 5: Magnified image (10.5x) of the anterior portion of SHGM L275 showing the position of the fin rays in the anal and dorsal fins. Scale bar $=0.5 \mathrm{~cm}$. 


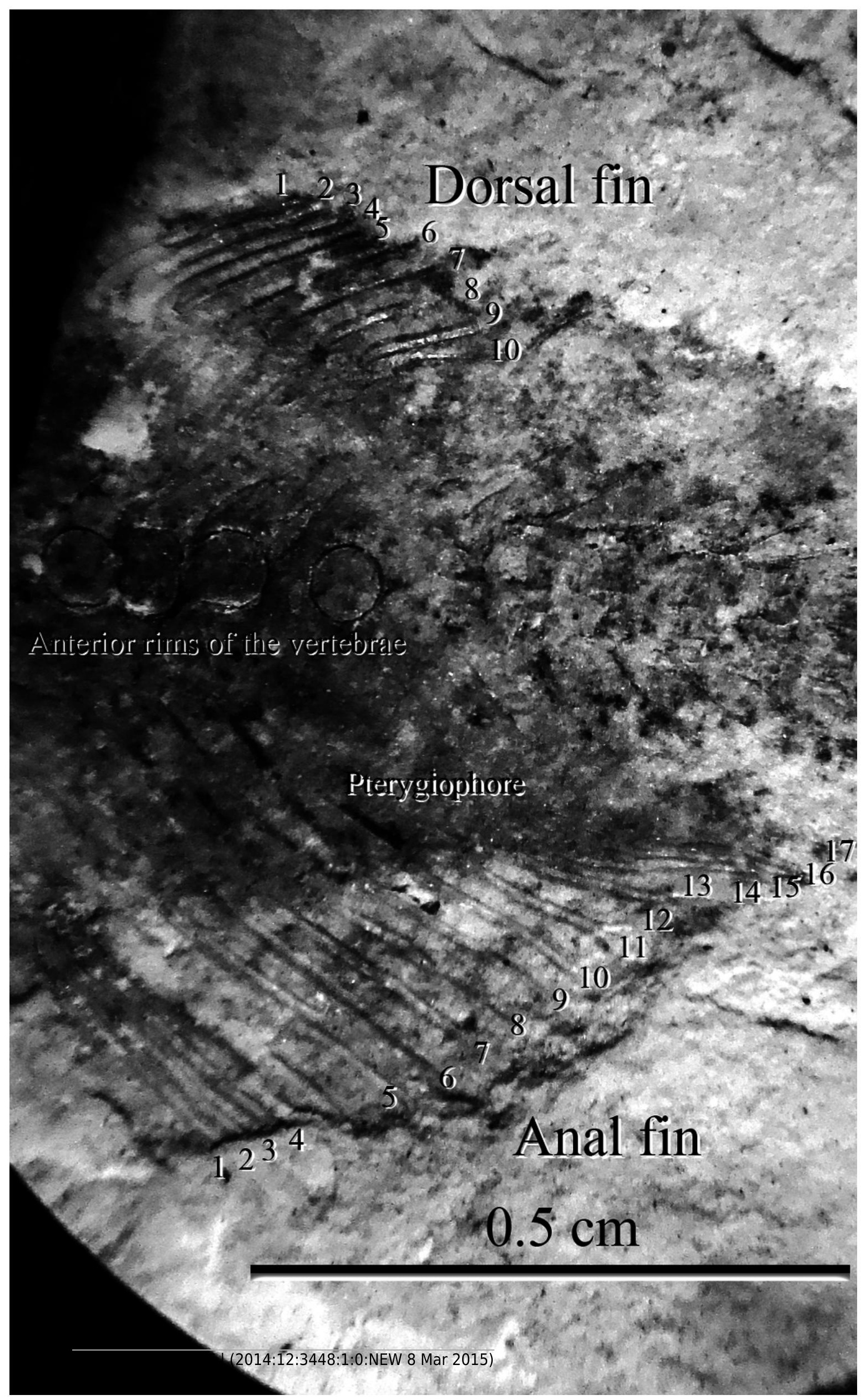


6

The caudal skeleton and bases of caudal fin rays in SHGM L275

Figure 6: Magnified image of the caudal skeleton and bases of caudal fin rays in SHGM L275, the arrows point to the outermost (unbranched) principal caudal fin rays.

Abbreviations: ep, epural; h1-6, hypurals 1-6; hsp2-5, haemal spines on preural centrum 2-5;

nsp1-5, neural spines on preural centrum 1-5; nspu1, neural spine on u1; ph, parhypural; pr.r, procurrent rays; pu1, preural 1; u1, u2, ural centra 1 and 2; un, uroneurals. Scale $=1 \mathrm{~mm}$. 


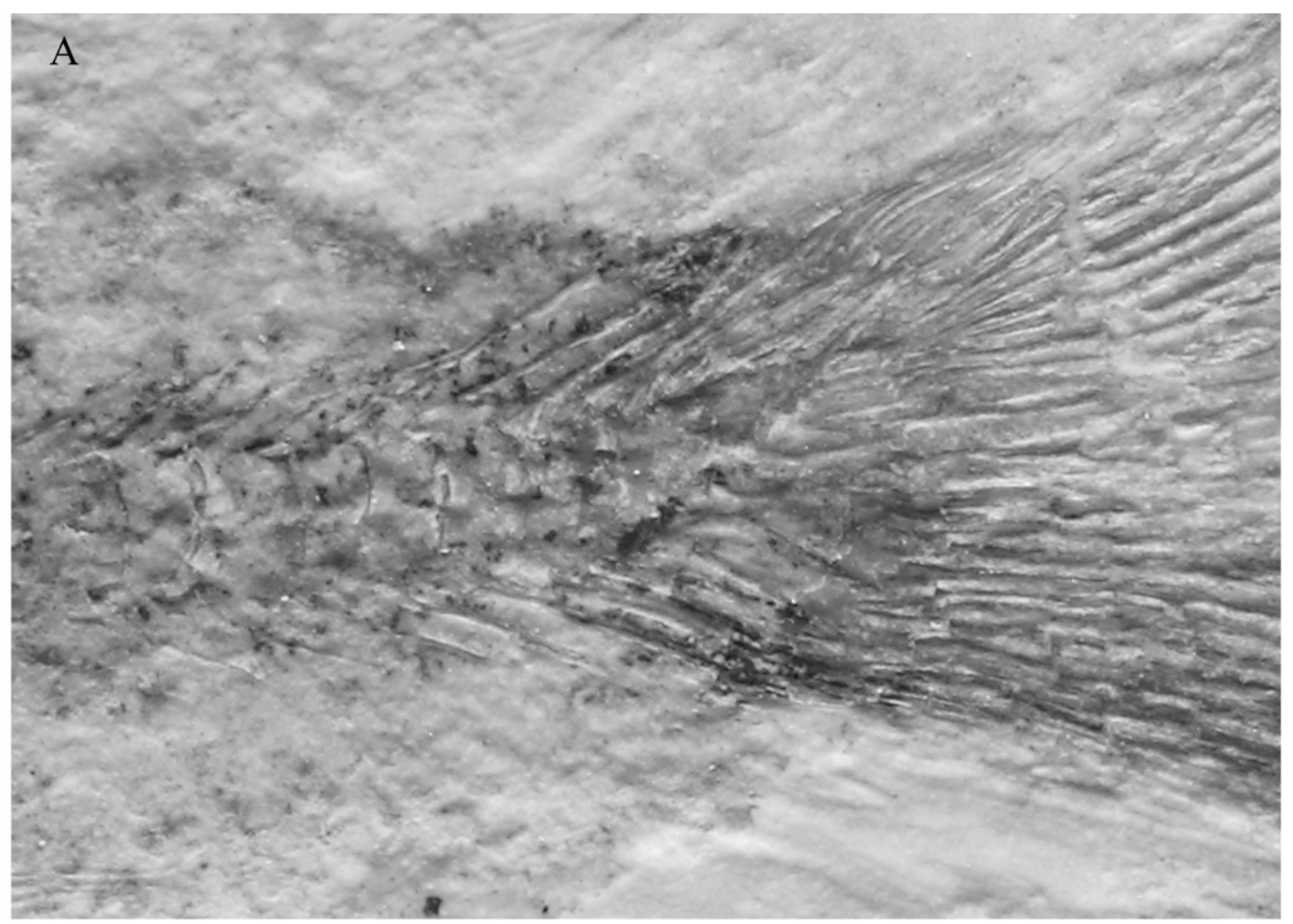

$\mathrm{B}$

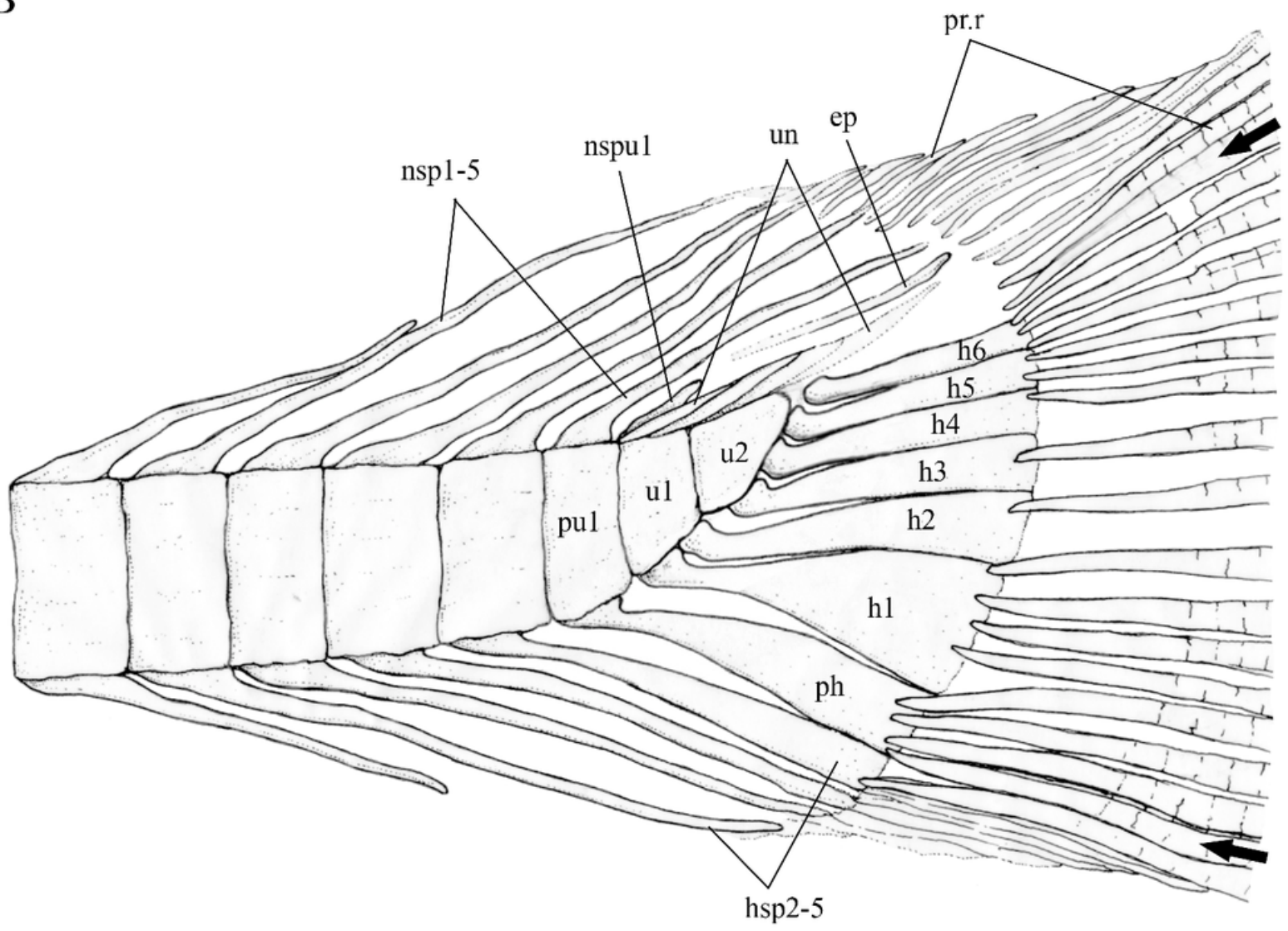


Table $\mathbf{1}_{\text {(on next page) }}$

Phylogenetic coding similarities between SHGM L275 and Paralycoptera

Table 1: The applicable characters from Shen (1996), Zhang (2006), Wilson \& Murray (2008) and Xu \& Chang (2009) to SHGM L275: coding similarities with the most closely-matched genus - Paralycoptera $(O=$ matched; $\mathrm{x}=$ not matched). For the codings of the individual studies please see Supplemental Tables S2-S5 in the Supplemental Information). 
2 Table 1: The applicable characters from Shen (1996), Zhang (2006), Wilson \& Murray (2008) and Xu 3 \& Chang (2009) to SHGM L275, coding similarities with the most closely-matched genus -

4 Paralycoptera ( $\mathrm{O}=$ matched; $\mathrm{x}=$ not matched). For the codings of the individual studies please see

5 Supplemental Tables S2-S5 in the Supplemental Information).

6

\begin{tabular}{r|cccccccc} 
Osteoglossomorph study & Equivalent character \\
& numbers \\
\hline Shen (1996) & 28 & 29 & 33 & 34 & 35 & 36 & \\
Zhang (2006) & 47 & 48 & 49 & 53 & 54 & 61 & 60 \\
Wilson \& Murray (2008) & 69 & 67 & 68 & 71 & & 65 & 64 \\
Xu \& Chang (2009) & 54 & 55 & 56 & & & 62 & \\
\hline SHGM L275 compared to Paralycoptera & $\circ$ & $\mathrm{x}$ & $\mathrm{x}$ & $\circ$ & $\circ$ & $\circ$ & $\circ$
\end{tabular}

7

8 


\section{7}

Skeletal reconstruction of Paralycoptera

Figure 7: Reconstructed skeleton of Paralycoptera (Xu \& Chang, 2009; used with the permission of the authors).

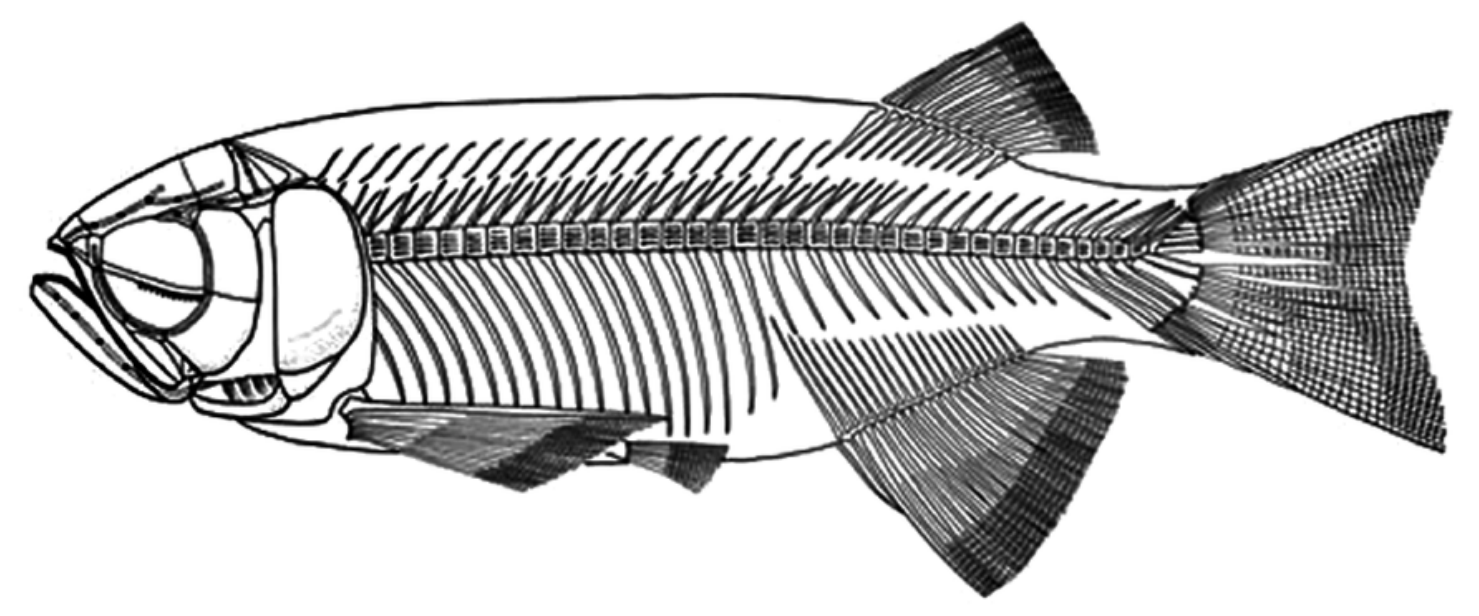


Figure 8 (on next page)

Chinese Paralycoptera localities

Figure 8: Paralycoptera localities in China (Locations from Chang \& Miao, 2004). 
9

Southeast Asian Jurassic fish localities and the localities of Paralycoptera

Figure 9: Jurassic fish localities in SE Asia and the localities of Paralycoptera (Modified from Chang \& Miao, 2004). 


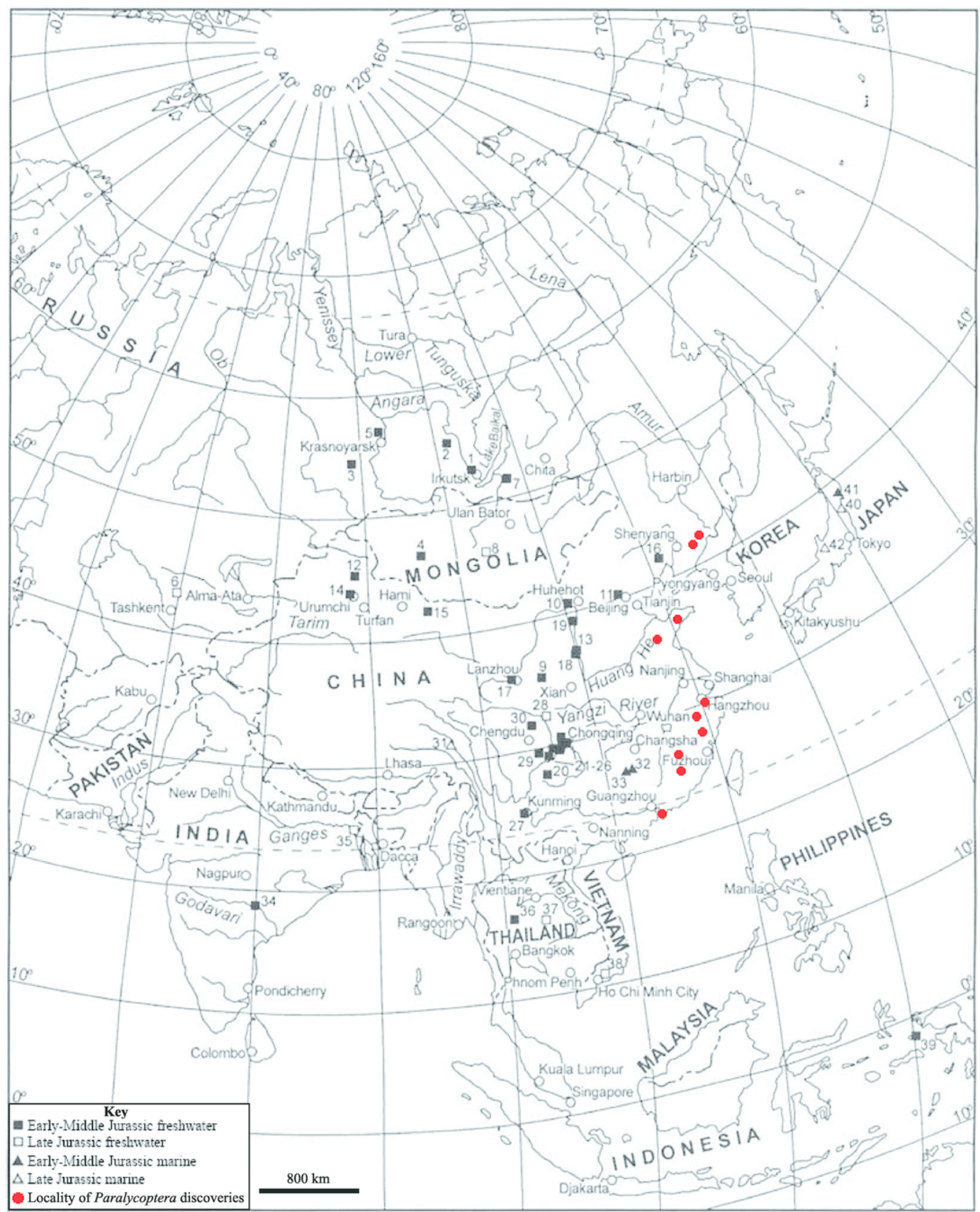


Table 2 (on next page)

The lithology of Paralycoptera-bearing formations

Table 2: Lithological characteristics of the formations preserving Paralycoptera. 
2 Table 2: Lithological characteristics of the formations preserving Paralycoptera. 3

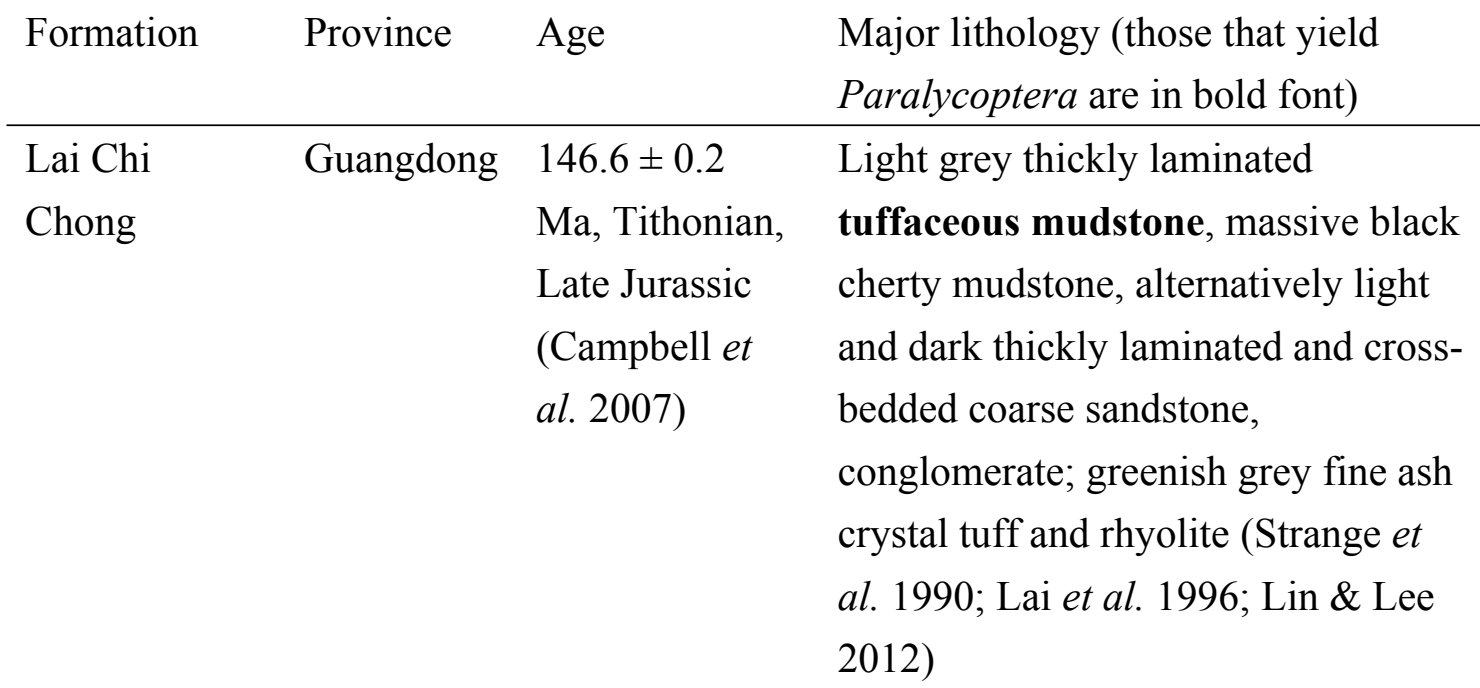

Fenshuiling Shandong Late Jurassic to Mudstone, shale, siltstone, sandstone, Early conglomerate and tuff (Wang 1985)

Cretaceous ( $\mathrm{Li}$ 1998)

\begin{tabular}{|c|c|c|c|}
\hline Guantou & Zhejiang & $\begin{array}{l}\sim 110 \mathrm{Ma} \text {, Early } \\
\text { Cretaceous (Xu } \\
\text { \& Chang 2009) }\end{array}$ & $\begin{array}{l}\text { Purplish grey, greyish green and } \\
\text { greyish yellow tuffaceous siltstone, } \\
\text { dark grey mudstone, purple } \\
\text { sandstone; andesite and tuff breccia } \\
\text { (Q.S. Chen 1983; Hu et al. 2012) }\end{array}$ \\
\hline Hengtongshan & Jilin & $\begin{array}{l}\text { Early } \\
\text { Cretaceous } \\
\text { (Han et al. } \\
2013 \text { ) }\end{array}$ & $\begin{array}{l}\text { Black mudstone, oil shale and tuffite } \\
\text { (Han et al. 2013) }\end{array}$ \\
\hline Baiyashan & Fujian & $\begin{array}{l}\text { Early } \\
\text { Cretaceous } \\
\text { (Zhang 2009) }\end{array}$ & $\begin{array}{l}\text { Purplish red conglomerate, siltstone } \\
\text { and sandstone (Zhang 2009) }\end{array}$ \\
\hline
\end{tabular}

